\title{
Women as heads of households in Germany and France: evidence from the 1846 censuses
}

Rolf Gehrmann

\section{Europa-Universität Viadrina, Frankfurt gehrmann.rolf@yahoo.de}

Fecha recepción 28.11.2015 / Fecha aceptación 06.04.2016

\section{Abstract}

This is the first study to be based on individual census data from 1846, and it analyses the position of women as heads of households in the former German Customs Union and France. The data provide information about an important stage of gender-specific life-courses, i.e. temporary or permanent function as heads of household. A cross-sectional comparison reveals regional features, differences between urban and rural areas and the conditions favourable to the formation of female-headed households. Certain forms of stem families were more conducive than the nuclear households; the textile industry more than metal crafts, the urban environment more than the rural, and even illegitimacy was a factor. Within rural areas, a comparison with earlier periods shows

\section{Resumen}

El presente trabajo es el primero en basarse en datos individuales de censos de 1846, y estudia la posición de mujeres cabeza de hogar en Francia y la antigua Unión aduanera alemana. Los datos presentan información sobre una etapa importante del ciclo de vida en función del género, es decir la función, temporal o permanente, de jefes de familia. Una comparación transversal pone de manifiesto las características regionales, las diferencias entre áreas urbanas y rurales, y las condiciones favorables a la creación de hogares encabezados por mujeres. Algunos tipos de familias troncales eran más propicios que los hogares nucleares; la industria textil más que la metalúrgica, el ambiente urbano más que el rural, e incluso la ilegitimidad era un factor determinante. En las áreas rurales, la comparación 
Monográfico | Women as heads of households in Germany and France: evidence from the 1846 censuses

a trend towards more female-headed households, whereas within towns this is less evident. Nearly all the German towns in the sample were still preindustrial, and the high rate of female-headed households was not linked to particular favourable employment facilities. The comparison with earlier periods also reveals a change in the definition of an independent household. Contrastingly, the legal framework had no great influence on this cross-sectional study.

\section{Key words}

census, households, women (gender), Germany, France, $19^{\text {th }}$ century con periodos anteriores muestra una tendencia al aumento de hogares con jefatura femenina, mientras que en los pueblos esta es menos evidente. La casi totalidad de los pueblos alemanes estudiados aún eran preindustriales, y no se encontró una relación entre la tasa elevada de hogares encabezados por mujeres y las oportunidades de empleo particularmente favorables. La comparación con periodos anteriores también demuestra un cambio en la definición del hogar independiente. Por el contrario, el marco jurídico no presenta una influencia considerable en este estudio transversal.

\section{Palabras clave}

censo, hogares, mujeres (género), Alemania, Francia, siglo XIX. 


\section{Introduction}

The issue treated here is an empirical one, and the questions we ask are quite simple: How many women were heads of households? Under what conditions did women become heads of households? Were there regional or social differences in the role played by them? Can they be explained by legal constraints, traditions, particular demographic and social circumstances? Among all these questions, the last three are the most interesting ones. They represent a particular challenge, since for our study we cannot rely on former research in this field. Such a categorical statement may be surprising, since female and gender history exists in Germany as well as in other countries, and is no longer a marginal discipline. It is fully integrated into historical research by now. Therefore, there are also publications on the situation of German women in the $19^{\text {th }}$ century, and there is research on the living situation of female workers and domestic servants, although to a far lesser degree than in France, and only in the form of isolated regional studies of little value for our purposes ${ }^{1}$. Other studies shed some light on the social situation that hindered marriages ${ }^{2}$. Otherwise research focused especially on women living alone or staying unmarried and stated for example North-South and rural-urban differences, which are explained by family models and economic opportunities ${ }^{3}$. The situation

1. A. Jorns : "Lebens- und Arbeitssituation von Frauen im Lande Braunschweig 1830-1865", in Braunschweigisches Jahrbuch, Beihefte, vol. 8, 1991.

2. K. Gröwer, Karin. Wilde Ehen im 19. Jahrhundert. Die Unterschichten zwischen städtischer Bevölkerungspolitik und polizeilicher Repression: Hamburg - Bremen - Lübeck, Berlin/Hamburg 1999.

3. C. Dauphin: "Alleinstehende Frauen", in G. Duby and M. Perrot (Dir.), Geschichte der Frauen, Bd. 5: 19. Jahrhundert, Frankfurt a.M. 1995, 481-497; J.M. Bennett and A.M. Froide (Dir.), Singlewomen in the European past, 1250-1800, Philadelphia, 1999; D. Simonton : "Widows and wenches: Single women in eighteenth-century urban economies ", in D. Simonton and A. Montenach (Dir.), Female agency in the 
of widows is a topic that is closer to our subject and better documented, since in general marital status was mentioned in census lists. Therefore, there is some evidence not only for England ${ }^{4}$, but also for the elderly in Germany and Austria ${ }^{5}$. The latter computes headship rates by female age groups without relating them to the total number of households. Even Fauve-Chamoux, who collected basic data for the frequency of female household heads all over Europe could not provide such information for Central Europe, Germany included ${ }^{6}$. Since then, Lanzinger has published such a statistic for a town and a village in Tyrol in 1849 and Ogilvie the sex ratio for household heads for the same configuration in Württemberg ${ }^{7}$. Recently a team from the Max-Planck-Institute for Demographic Research went further in this direction with a study on the town of Rostock ${ }^{8}$.

Thus, there is some material for Europe, but the regional imbalances on this continent lead to the situation that the major work on German women with subjects concerning our study is more than thirty years old. Even that book contains only a small number of studies of the social situation of women of the popular classes, most of them being dedicated to cultural aspects and outstanding personalities. Unfortunately the assessment of the editor that " disappointingly little research has been done on the working life of working-class women in Germany or Central Europe in the nineteenth century " ${ }^{9}$, is still valid today, although there are some studies on female work in the pre-industrial $19^{\text {th }}$ century by now ${ }^{10}$. For early modern times and especially for towns there are more studies, since historians of the $19^{\text {th }}$ century have discovered the surplus of women ${ }^{11}$. Ogilvie, for example, analyzed in a thorough study women's economic role in Württemberg ${ }^{12}$.

urban economy: Gender in European towns, 1640-1830, New York, 2013, 93-115; see also T.K. Hareven and L. A. Tilly: "Solitary women and family mediations in two textile cities: Manchester and Roubaix", in Annales de Démographie historique, 1981, 253-271; R. Wall: "Women alone in English society", in Annales de Démographie historique, 1981, 303-317; B. Hill, Women alone: Spinsters in England, New Haven/London 2001.

4. B. Moring, Beatrice: "Rural widows, economy and co-residence in the 18th and 19th centuries ", in History of the Family, vol. 15, 2010, 239-254.

5. J. Ehmer, Josef: Sozialgeschichte des Alters, Frankfurt, 1990.

6. A. Fauve-Chamoux: "Famille et ménage en Europe urbaine préindustrielle: grandes et petites villes", in Société d'histoire des petites villes (Dir.), Petites villes et histoire, vol. 1, Mamers 1998, 7-20.

7. M. Lanzinger, Das gesicherte Erbe. Heirat in lokalen und familialen Kontexten. Innichen 1700-1900, Wien, 2003; S. Ogilvie, A Bitter Living: Women, Markets, and Social Capital in Early Modern Germany, Oxford, 2003.

8. M. Szołtysek, S. Gruber, B. Zuber-Goldstein, and R. Scholz : "Living arrangements and household formation in an industrializing urban setting: Rostock 1867-1900”, in Annales de Démographie historique, vol. 2, 2011, 233-269.

9. J.C. Fout (Dir.), German women in the nineteenth century: a social history, New York, 1984, p. 11.

10. P. Hudson and W. R. Lee (Dir.), Women's Work and the family economy in historical perspective, Manchester 1990; D. Simonton: "Widows and wenches..." loc. cit.

11. M. F. Wiesner: "Having her own smoke", in J.M. Bennett and A.M. Froide (Dir.), Singlewomen in the European past, 1250-1800, Philadelphia 1999, 192-216.

12. S. Ogilvie, A Bitter Living... op. cit. 
We have to deal with this situation and must look for other areas of intersection between mainstream historiography and the empirical findings based on micro-data extracted from census lists. Such an area is the current research on women's rights ${ }^{13}$. It helps to understand how legal constraints may have limited the possibilities for household formation in the past. In this literature, the prevailing opinion is overwhelmingly negative, which is in line with the prevailing tendency in older female history to emphasize the role of women as victims ${ }^{14}$. Another hypothesis is about important differences in Europe. Generally, it is supposed that German unmarried women were, unlike British women, not allowed to head a household in the $18^{\text {th }}$ century $^{15}$. Such claims can be tested. Thus, history of legal systems cannot only help us to interpret empirical findings based on census data, but also assessments based on normative literature can be controlled by this kind of data. Finally, it must be emphasized that a large-scale study on Germany which is based on individual data covering entire populations at a given moment can be called pioneering work. May this appraisal excuse the imperfections and the limited scope of a research, which is in its early stages.

\section{Laws}

Before presenting the German and French data in a second section, we should consider the legal systems in both countries. Surprisingly, there were few differences between France and Germany, or at least these differences were not fundamental ones. Even though the laws were not the same, in the $19^{\text {th }}$ century women could manage households on their own on both sides of the Rhine. Of course, neither women's rights were equal to those of men, nor were they equal in different countries and states. This kind of discrimination is supposed to be visible in the composition of households. Therefore, it is useful to present briefly the diversity of legal systems, not only between France and Germany, but also inside of the conglomerate of states that formed the German Confederation of the major part of the $19^{\text {th }}$ century. Besides the Code civil, three other major legal systems were applied after the French Revolution. The most important was the Prussian Common Law (Allgemeines Landrecht), followed by the German Common Law (Gemeines Recht) and the reign of ancient particular laws, each of these systems being the reference in one German province or another. The map of women's rights was thus quite variegated (fig. 1).

\footnotetext{
13. For a recent example see H. Carius, Recht durch Eigentum: Frauen vor dem Jenaer Hofgericht (16481806), Oldenbourg, München 2012 and more general A. Duncker, Gleichheit und Ungleichheit in der Ehe, Böhlau, Köln/Hannover 2003, and B. Dölemeyer: “Frau und Familie im Privatrecht des 19. Jahrhunderts”, in U. Gerhard (Dir.), Frauen in der Geschichte des Rechts: Von der frühen Neuzeit bis zur Gegenwart, München 1997, 633-658.

14. H. Carius, Recht durch Eigentum... op. cit., p. 11.

15. S. Ogilvie, A Bitter Living... op. cit., p. 271.
}

Revista de historiografía 26, 2017, pp. 167-186 
The main differences were about the question, of whether a woman could have legal capacity and thus be legally competent ${ }^{16}$. Only in some parts of Germany were these rights completely acquired, for instance in Mecklenburg, Lower Saxony and Hessen. Elsewhere, there was theoretically a fundamental difference between unmarried and married women. As in the area of the Code civil, unmarried women were privileged in the regions under Prussian Common Law. There, the situation was quite different from that described by Ogilvie for the $18^{\text {th }}$ century. However, everywhere marriage was considered as an act of submission to the authority of the husband. For the biography of most of the women, this meant that they shifted from the rule of the father to the rule of the husband. Theoretically it was possible that an unmarried daughter could acquire legal independence, but this was bound to the condition that her father agreed in due form. So much for the theory. In reality, it is more than doubtful that such distinctions were of any importance outside the upper class, and that means for the majority of young women in the $19^{\text {th }}$ century. They had not to deal with property rights, and mortality, for instance, was more likely to give full autonomy to young women than a formal declaration at the notary's. Domestic service opened another opportunity to a life far from parental authority. For example in Brunswick the majority of former domestic servants lived in their own household ${ }^{17}$.

However, legal constraints could become reality when women had to go to court. In some parts of Germany, even otherwise independent unmarried women were not legally competent, so that they needed a guardian in legal affairs. In Saxony and Bade, as in Württemberg, they could not appear in court alone. Doubtlessly this was often for pure form ${ }^{18}$. Nevertheless, these customs can be seen as the expression of a proscription of an unrestricted female independence, and thus the gender tutelage could have had an influence on household formation. Even in the best case, in Prussia as well as in France, independence - and with it the capacity to head a household - was linked to celibacy or widowhood. Unmarried mothers had the same rights in this regard, although in Prussia a guardian had to be named for the education of the children. Otherwise, living with a man always meant being married. Concubinage was not a legal institution, but it was rather considered as a public offense (öffentliches Ärgernis), necessitating the intervention of public authorities. So far, there was no major discrepancy between France and Germany. Just in one particular case was the Prussian law fundamentally different from the French Code civil. With respect to a separation of couples, the former was distinctively more liberal than the latter, and it stayed so even through the Restoration period after 1815. Whereas divorce was abolished in France in 1816,

16. E. Holthöfer : "Die Geschlechtsvormundschaft: Ein Überblick von der Antike bis ins 19. Jahrhundert”, in U. Gerhard (Dir.), Frauen in der Geschichte des Rechts: Von der frühen Neuzeit bis zur Gegenwart, München 1997, 390-451.

17. A. Jorns : "Lebens- und Arbeitssituation... loc. cit., p. 97.

18. D.W. Sabean : "Allianzen und Listen: Die Geschlechtsvormundschaft im 18. und 19. Jahrhundert", in U. Gerhard (Dir.), Frauen in der Geschichte des Rechts: Von der frühen Neuzeit bis zur Gegenwart, München 1997, 460-479, cit. p. 461. 
Prussia maintained the principle established in 1794. Mutual aversion was a sufficient reason for dissolution of the marriage.

With this additional possibility the list of legal opportunities for women to found their own household around 1846 is complete. They had to be either widow, divorced or unmarried women. If they were single women, they had to have their own income and have been released from the authority of the father. Under which circumstances did they live then? What was their number in comparison to women who were in the same legal condition, but who lived in a subordinate position in another household? Census data can help to answer some of these fundamental questions. Other problems must stay unresolved, for example the assessment of the choices of people manifest in data. Were they made voluntarily or were they caused by pure necessity? We cannot pretend to find it out by analyzing the data only, but we cannot go further for the moment.

\section{Data}

The material we will use here is made of micro-data from the census of 1846. They have been collected by the MOSAIC project of the Max-Planck-Institute for Demographic Research, Rostock. In a first step, only German data were prepared for a survey on 1846, which seemed to ensure a sufficiently large coverage. Later a big data set for France for the same year became accessible too, so that a wider range of comparisons is possible now. Overall, our study is based on $17^{\prime} 000$ individual data from rural France, $20^{\prime} 000$ data from rural Germany and 11'000 from German towns. It must be noted that in this special case « Germany » means the German Customs Union, which is the later German Empire less some northern states like Hanover, Mecklenburg or the duchies of Schleswig and Holstein. In this area genuine census lists were established every three years in order to get the most exact possible number of people in order to redistribute the toll revenues equitably. Despite their large geographical coverage, the lists preserved to date are mainly Prussian ones. Their quality can be considered as good, since they respond to the standard requirements for comparable census micro-data, as

- each individual is listed with its age, its profession and marital status,

- households are clearly separated and the relationship of each person to the head of the household is indicated explicitly or implicitly.

Unlike in French listings, there was no column for the marital status in the German forms, but in virtually all cases, it is self-evident. The same is true for the identification of the status of children, whether legitimate or illegitimate. The French census-taker expressed this feature by the remark "enfant naturel », whereas German officials showed more discretion on this subject. In France, the conditions for scholars are also more favorable with respect to the availability of data. Archive files are not concealed in different archives at variable administrative levels and under changing titles, but clearly identifiable and more and more digitized. There is so much material that a random sample for the whole country can be drawn, whereas in Germany the material is relatively rare and regionally clustered. Unfor- 
tunately, the rural areas of Southern Germany and big parts of Eastern Prussian provinces are not represented in the sample of 1846 (fig. 2). For those regions, material exists for later census years, however.

A last introductory remark is about the identification of the head of the household. Ordinarily it is named first. However, in France there are some cases, where the mother of the "chef de ménage " - who is explicitly called so - appears in the first place. These may be psychologically interesting laps, but these women cannot be counted as household heads. A similar phenomenon exists in the lists of the German region of Brunswick. There, retired mothers were even separated from the household of their sons or daughters, with the consequence that there are unusually few extended and too many one-person households, although these mothers probably lived with their kin. Economically they were independent, however, since they lived in general from the resources that were guaranteed by contract. For comparison, we must consider these persons alternatively as heads of their own or members of the main household of the farm. All in all, there are not a big number of such equivocal cases, and the identification of female household heads is simple.

\section{National or regional structures?}

In order to compare Germany and France, we can only consider the rural areas. This analysis is based on a respectable amount of data, namely 8'500 households, retired farmers named «Altmütter» and «Altväter» being excluded as ambiguous cases. At first sight, the two countries seem to show distinct characteristics. In total, the percentage of females as household heads was higher in France than in Germany (18.1\% as compared to $15.3 \%$, or $18.1 \%$ as compared to $15.9 \%$, if Altmütter and Altväter are considered as heads of their own household). Nevertheless, is this a significant or even a fundamental national difference? Introducing regional variations opens a new perspective on the problem (fig. 3). Actually, mean values of French regions excluding the Pyrenees and those of Germany east of the Rhine were almost identical (Germany 16.5\%, France 16.3\%). Contrary models are represented, not by most of the German and French regions but by the Pyrenees and Left-Rhine Germany, which range on the extreme positions of the scale. What kind of household structure do they represent?

There is a surprising relationship between household forms and female autonomy. The correlation between the percentage of female-headed households and the frequency of nuclear households is clearly negative (fig. 4). In a manner of speaking, the latter could be called a domain of patriarchs - which fits badly with the idea of a patriarch as the keystone of an extended household. In the sample relating to the Rhenish villages a nuclear household was synonymous with small economic units consisting of the couple and their children. There is not much place for other configurations and it brings to mind the old concept of « proletarian 
households $»^{19}$. On the other hand extended households were not generally correlated to a larger part of female household heads either. This holds for the stem family of southern and central France, but not for the Westphalian stem family. Different demographic, economic and cultural factors may have contributed to the outstanding position of the Pyrenean stem family, which is relatively well known in research ${ }^{20}$. This result may be an incentive to look closer at the position of women in the household in comparative research on stem families. In our study, we focus exclusively on female-headed households as a distinct sub-group, in order to learn more about their characteristics.

It becomes evident that within this subsample France and Germany share many common features, partly due to sex-specific demographic indices like age at marriage and survival rates. Three fourths of female household heads were widows, one-fourth women who were unmarried or did not live together with their husbands (tab. 1). However, main differences existed in the presence of children. Naturally, it is linked to the total number of surviving children. With respect to this, probabilities were lower in France, since there demographic transition had already begun in 1846 . Consequently, there were more widows living alone or in other household configurations than with children. Celibacy did not make the difference. The proportion of singles without any other person in the household was nearly identical, that is 11 to 12 percent.

A short look at the data on elderly women teaches us that the differences between France and Germany are explained to a large extent by the forgoing arguments. Life expectancy was similar in both countries, so that the proportion of widows to widowers, being at least 45 years old was the same, which is 2.1:1. The proportion never married, however, correlated positively with the percentage of female household-heads. This also holds for the separated. More intriguing is the fact that there were twice as many women in France, who did not live with their husbands. It can be supposed that these findings were biased by temporary migrations. In France, the census was taken in summer, in Germany three weeks before Christmas. If the term of the census had an effect, then the local officials in France were not able to follow to a hundred percent the directive to count the resident population. Furthermore, these distortions may also be a part of the explanation of the striking presence of women among Pyrenean household heads, as observed in fig. 3.

Conditions for the decline of the proportion never married become evident by comparing the different regions, including here, in anticipation, also towns. The data can be interpreted as follows: When there was enough work for men in the surrounding area, and little need for domestic servants, then the proportion of women who never married declined drastically. This is particularly eye-catching in the case of Höhscheid, a metal-laborer town adjacent to Solingen, where a low rate of final celibacy (age group 45 to 50 ) of $7.1 \%$ was as-

19. H. Rosenbaum, Formen der Familie. Untersuchungen zum Zusammenhang von Familienverhältnissen, Sozialstruktur und sozialem Wandel in der deutschen Gesellschaft des 19. Jahrhunderts, Frankfurt a.M. 1982.

20. A. Fauve-Chamoux : "The Stem Family, Demography and Inheritance: The Social Frontiers of AutoRegulation“, in R.L. Rudolph (Dir.), The European peasant family and society: Historical studies. Liverpool 1995, 86-113. 
sociated to a low singulate mean at marriage of 22.5. For an urban environment in mid-1 $9^{\text {th }}$ century Germany, this was extraordinary, at least in the west. All these demographic indices suggest that women in the given historical and geographical context did not stay alone by their own choice (which does not mean that they always married by choice). Thus, nothing points to a conscious deviation from a general marriage pattern, which was common in France as in Germany.

Especially interesting is the question of how unmarried mothers were integrated into households or, if not, how often they headed their own household. Our data shed a first light on this, without the possibility to make further comparisons in the given historical context. Even for the 1846 census list, we can only overcome the lack of precision in the indications by an appropriate processing. Then the data reveal that for these women the opportunities to establish their own household were not fundamentally different in Germany from France. More than $40 \%$ of unmarried mothers had this possibility (40.7\% in Germany, $45.6 \%$ in France) (tab. 2). In Germany it was nevertheless more frequent that mothers of illegitimate children stayed in the households of their parents. Despite this - and this is a remarkable fact - the rate of illegitimacy still correlated with the number of women as household heads (see Coburg (letter « $\mathrm{h}$ » in fig. 2) and Helmstedt (letter « $\mathrm{f}$ » in fig. 2)). When eventually one takes into consideration the smaller number of French widows who lived with their children, as well as other aspects of the living arrangements of unmarried mothers, then some more general conclusions can be drawn. It becomes obvious that there was a stronger tendency to neo-locality in France. Taking into account furthermore the absence of men, one can argue for a greater mobility in general. In both senses, France was really more " western », or, better said, economically advanced.

Concerning the last category of women, those who were not or no longer married, i.e. divorced persons, a strong discrepancy between the focuses of the history of law and the findings of quantitative social history appear. There was, for instance, not even one case of divorce in the rural sample, whereas this subject plays a major role in the history of law. As opposed to this, a major problem of social history is the situation of widows and unmarried mothers, which does not attract attention in research based on normative sources.

\section{Social factors}

The range of professions in the German data set is much more biased towards agricultural work than are French data, which may be partly due to the nature of the sample, as described above. Day laborers (40 of 149 cases) and female workers dominated in the subgroup of unmarried women in Germany, and among the widows those of peasants and former peasants prevailed. In the French sample, the presence of a textile crafts is an outstanding feature. It is correlated to the frequency of female household heads, among them an amazing number of spinners (131). Most of them were widows (79), fewer celibates (40). Textile industry is mentioned in many regions, and one may argue that it was only a side job, which would have been omitted in a similar case in Germany. However, this cannot be the whole story. In five villages in the French sample, professions in that industry are so frequent that a substantial 
bias in the recording of the census information can be excluded (fig. 5). Generally speaking, it can be concluded that there was a positive relationship between the nature of female employment and the frequency of female household heads. Textile industry is in contrast to metal industry, as has been seen for Solingen. Without these "fileuses" and "filandeuses " on the French side and without the retired farmers of Helmstedt on the German side of the border, the percentage of female household heads would have been equal: $15.3 \%$ in Germany and 15.4\% in France! This figure seems to represent a kind of common baseline.

The comparison between female headed households in urban and in rural areas can provide further insight into the influence of employment opportunities on the living conditions of women. Unfortunately, we can realize it only for the German sample. There, 4'000 rural households in 1846 can be contrasted with 2' 400 households from eleven towns and cities, which are more equally distributed over Germany than the villages in the rural sample (fig. 1). As already deduced from general overviews ${ }^{21}$, there were significantly more households headed by women in towns (20.7\%, as compared to $15.3 \%$ in the countryside). What was precisely the reason for it? Were there more job opportunities than in the countryside? Was there a higher incidence of unmarried women or a specific age-structure, which could have been an outcome of migration?

Once again, information of women's income is virtually absent. In French and other census lists, for example from Denmark and Schleswig-Holstein, at least poor relief is mentioned. In the GCU sample, such information was not required. Specifications of earnings from any economic activity are missing in towns even more often than in the countryside. Even when taking as proxies the indications of social statuses, we still do not learn anything about $41 \%$ of female household heads. Moreover, the entries in the census lists are not very enlightening. Common denominations like " day laborer " prevail, though on a smaller scale than in the countryside (12.5\% with this general status in towns, $22.6 \%$ in rural areas). As we have seen, in France the situation was different. Although disappointing, this is thus also a clear result. It must be concluded that even in towns there was no evidence for a major business activity other than the unspecific occupation of day laborer. It would be indispensable to consult tax registers and other similar documents in order to get more information, if ever this should be possible. If the sources of income were important, they would not have been neglected in census list either. Thus, we can conclude by the absence of such information that the higher frequency of households in town must have had other reasons than employment facilities.

Nor is the composition of female-headed households the key to the explanation of the problem of urban-rural differences. Note that domestic servants are not taken into consideration here, because they were not members of a community of living in a restricted sense. In towns and in villages there was a similar distribution of the different categories of widows and other single women (tab. 3). In urban as well as in rural areas, more than half of the households were composed of widows with their children. It is somewhat surprising, however, that the category of single women was not distinctive to a higher degree. In

21. A. Fauve-Chamoux: "Famille et ménage... loc. cit. 
towns, there were neither more unmarried singles nor more solitary widows. Noteworthy is only the frequency of women who lived without children, but at the same time not alone. Apparently, towns provided more opportunities for living arrangements other than the nuclear family household.

Living as a single without parents or children did not mean that kinship was not important. Especially younger sisters were appreciated or supported. Contrary to brothers, they are relatively often mentioned as boarders (tab. 4). Other relatives could also share the household of single women, for example foster children as their names suggest. Only female communities formed households beyond kinship relationship. They had an impact on the urban-rural difference, although their number was not impressive (four female inmates in rural, 11 in urban areas). In the countryside, these inmates were called « without status». In towns, they formed a group, which was mainly constituted of working women and widows. For example, in three households two widows lived together.

Theoretically, it could be an interesting question to ask whether isolation was the price to pay for greater independence offered by an urban environment. Again, the statistical evidence contributes to relativize such questions. Consider isolation as absence of all kinship ties within the household - nothing else can be measured - then it must appear here as a oneperson household or a household, in which a woman cohabitated only with domestic servants and employees. Indeed such household compositions were more frequent in towns, but after all, even there it was only a minority of a fourth of all female-headed households. Typical for the towns examined here, although not of an overwhelming importance in quantitative terms, proved households, in which women lived together with housemates. Within this subsample, the community with another woman seemed the most opportune, and perhaps the most accepted by society. It could also serve as a panacea in the case of social conditions, where means for the employment of domestic servants to share the daily life were missing.

\section{Discussion}

How do these results fit to what we already know about the living situation of women and the importance of female-headed households in preindustrial times?

In comparison to today's values, their part was certainly small. In present-day Germany in more than a third of all households the or $a$ woman is the major earner (14'145 from $40^{\prime} 656$ households of the micro-census 2012 , which is $34.8 \%{ }^{22}$. However, even in preindustrial times, values of more than $20 \%$ were not rare in urban areas. The example of Reims $(22 \%)$ is well-known ${ }^{23}$. The situation in Berlin was similar. The oldest census with a specification of female households shows $25.0 \%$ in the Prussian capital (1805). In 1871, the rate was still in the order of $20 \%$ ( $20.7 \%$ - that is exactly the value of the urban sample for 1846$)$, to

22. Statistisches Bundesamt, Haushalte und Familien: Ergebnisse des Mikrozensus 2012, Fachserie 1, Reihe 3, Wiesbaden 2013.

23. A. Fauve-Chamoux: "Famille et ménage... loc. cit. 
decline afterwards $(17.4 \% \text { in } 1875)^{24}$. Unmarried women were generally more often heads of households than bachelors were. Obviously, this was a constant. Otherwise, the position of women in households was not always described precisely by census lists, and even less by soul-tables. That makes it difficult to work out trends in medium terms, and even in relation to the Middle Age. So we will renounce the attempt to interpret the rates of female-headed households that have been calculated for some German towns in the Middle Age, more precisely the $14^{\text {th }}$ to $16^{\text {th }}$ centuries. For instance, social historians found out that in the middleRhine region values ranged from $16 \%$ to $25 \%$, thus absolutely within the variation expected from the results from the $19^{\text {th }}$ century ${ }^{25}$.

For rural areas, there are not many data for comparisons. Holstein in 1803 is an exception. There, one household out of eight $(12.8 \%)$ was headed by a woman, which is a relatively high number ${ }^{26}$. We must go back further in order to obtain some other interesting observations. For a Württemberg mountainous region, which in some respects showed characteristics similar to our Pyrenean subsample, Ogilvie ${ }^{27}$ gives a detailed account of the "soultables ». It reveals that there was a certain number of fellow occupants, who in a census list of the $19^{\text {th }}$ century would have been counted as independent households and who already in early modern Württemberg were to a large extent considered to be « responsible for their own independent livelihood $»^{28}$. Without the fellow occupants however, only $5 \%$ of the Wildberg households in 1717/22 were headed by women. In 1736 four fifths of the never-married females who were recorded as responsible for their own livelihoods were spinsters, $9 \%$ lived with younger sisters and just as many with illegitimate children. This was completely different from the German census sample from 1846, where only half of them were spinsters and two fifths lived with their children (tab. 1). As in Wildberg, the households consisting of sisters represented an identifiable group, although it was no longer quantitatively important.

The latter comparison shows that the real living situation of women could be less different than it is suggested by the formal classification by households, and the problem of the definition of household is linked to the legal framework. We have seen that the Ogilvie data are somewhat biased by the concept that an unmarried woman could not be the head of a household. For 1846, the legal definition of what could be considered as such must have been important too, although census-takers in villages were controlled more strictly for the exact number of people than for their attribution to households. On the other hand, the regional concepts that were at work were certainly not independent of regional laws. In the $19^{\text {th }}$ century, economic independence became the sole criteria for the definition of a household, as it

24. R. Boeckh, Die Bevölkerungs-, Gewerbe- und Wohnungsaufnahme vom 1. December 1875 in der Stadt Berlin, Berlin 1878, vol. 2, p. 54.

25. K. Wesoly: "Der weibliche Bevölkerungsanteil in spätmittelalterlichen und frühneuzeitlichen Städten und die Betätigung von Frauen im zünftigen Handwerk (insbesondere am Mittel- und Oberrhein)", in Zeitschrift für die Geschichte des Oberrheins, vol. 128, 1980, 69-117; Wiesner, op. cit.

26. Lanzinger, op. cit., p. 304.

27. S. Ogilvie, A Bitter Living... op. cit., p. 271.

28. S. Ogilvie, A Bitter Living... op. cit., p. 61.

Revista de historiografía 26, 2017, pp. 167-186 
can be shown by the Prussian instructions for the census-takers. Households were no longer considered as a "Familie » in the traditional sense of the term, which means under the rule of a « Hausvater ", the chief of the farmstead for example. Already in the $18^{\text {th }}$ century, property became more important than status or $\operatorname{sex}^{29}$. In the $19^{\text {th }}$ century, the same holds for income or « independent livelihood».

The legal framework was probably important for the evolution of rates in time, but it is only of little help for the explanation of the cross-sectional diversity in our sample. For towns, the classification of the 22 sub-samples by the four degrees of legal autonomy (fig. 1) does not give a conclusive result. As expected, the lowest part of female-headed households was encountered in a region with a relatively low level of female rights (West Prussia), but in Stuttgart, with a similar legal background, it was high. Other factors were certainly more important in urban areas. The legal background partially explains the high rate of female households in Brunswick (sub-sample « $\mathrm{f}$ » in fig. 1), however, but the high rate of illegitimacy places Coburg (sub-sample « $\mathrm{h}$ » in fig. 1, with cura maritalis and limited cura sexus) at the top of all rural areas.

Doubtlessly the information from the 1846 census lists is of basic importance, although comparisons with other sources are problematic and trends are difficult to detect. Research on census data can only provide some pieces to the puzzle of the living situation of German women in the $19^{\text {th }}$ century. Not all of it has been presented here. It is possible to compute for example the mean age of leaving home or the mean age at marriage. As to the features of female-headed households presented here, regional differences have become evident and socio-economic characteristics have been recognized, whereas the impact of the legal framework has been relativized. If there was an impact of culture on the data analyzed here, then it was not due to nation or language, but to household forms, which, as might be argued, finally depended on economic and ecological conditions.

29. H. Carius, Recht durch Eigentum... op. cit., p. 14. 


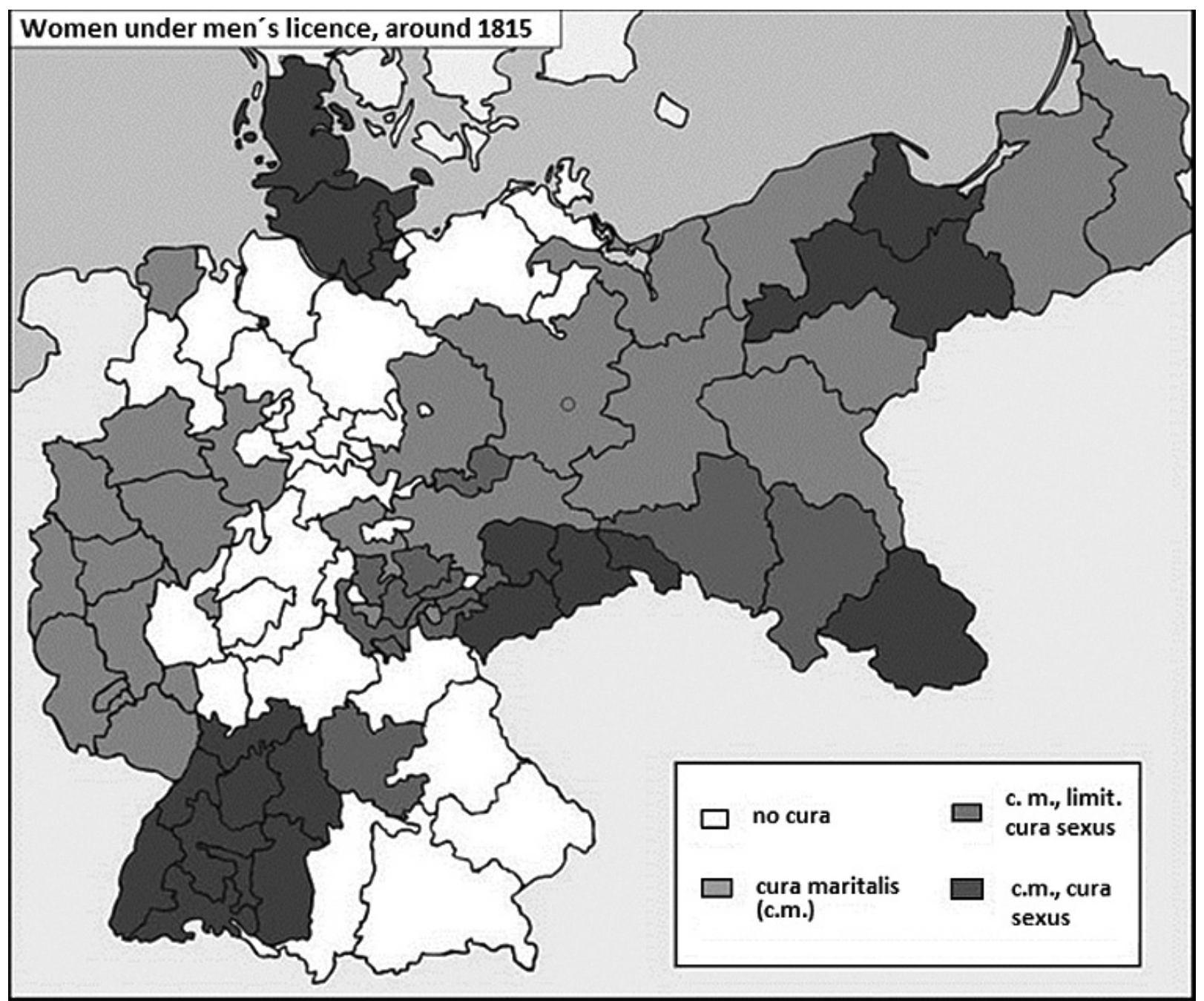

FIG. 1 Women's rights around 1815

Source: Holthöfer, op. cit., p. 437. 
Monográfico | Women as heads of households in Germany and France: evidence from the 1846 censuses

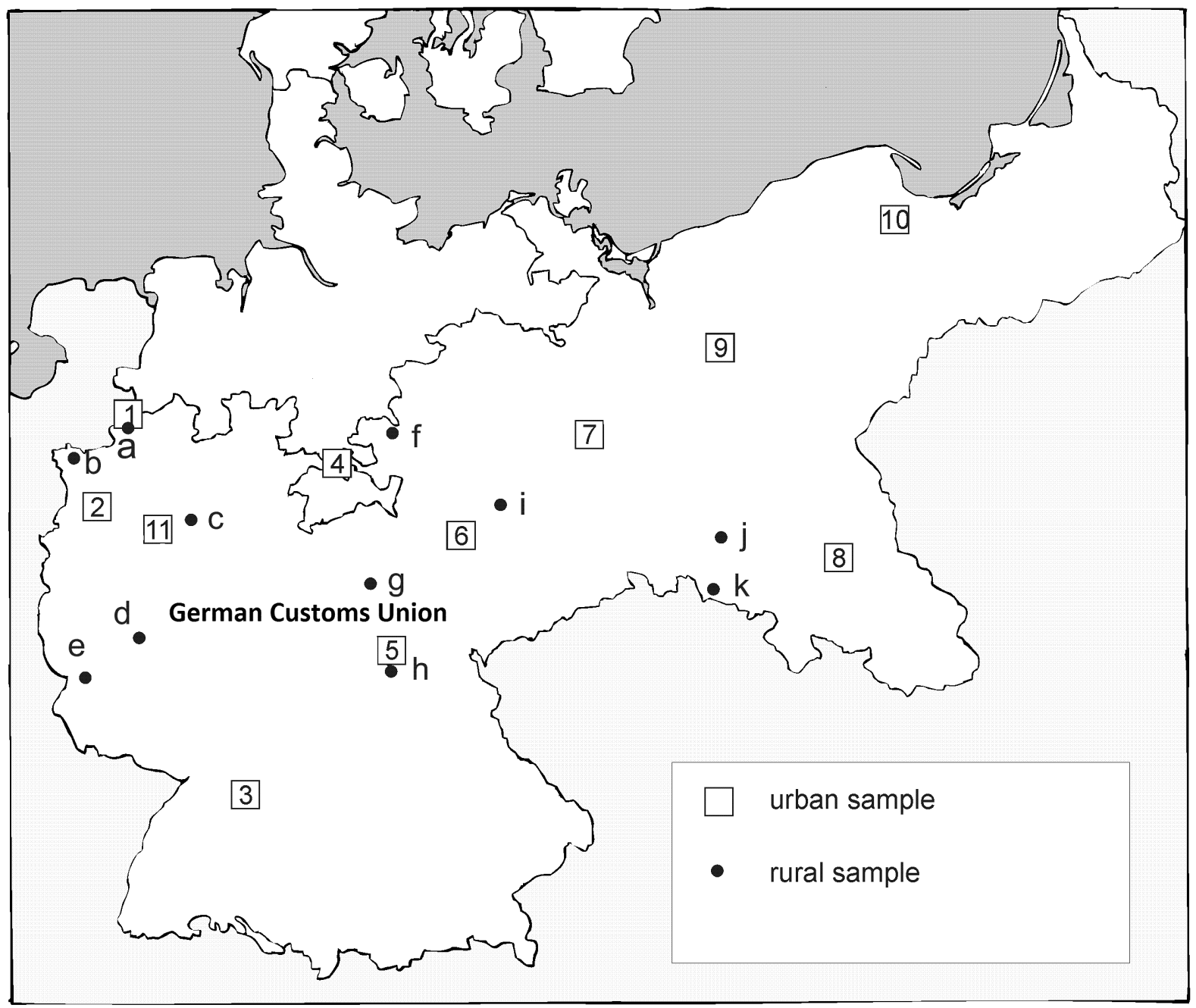

FIG. 2 Sample of 1846 German census lists 


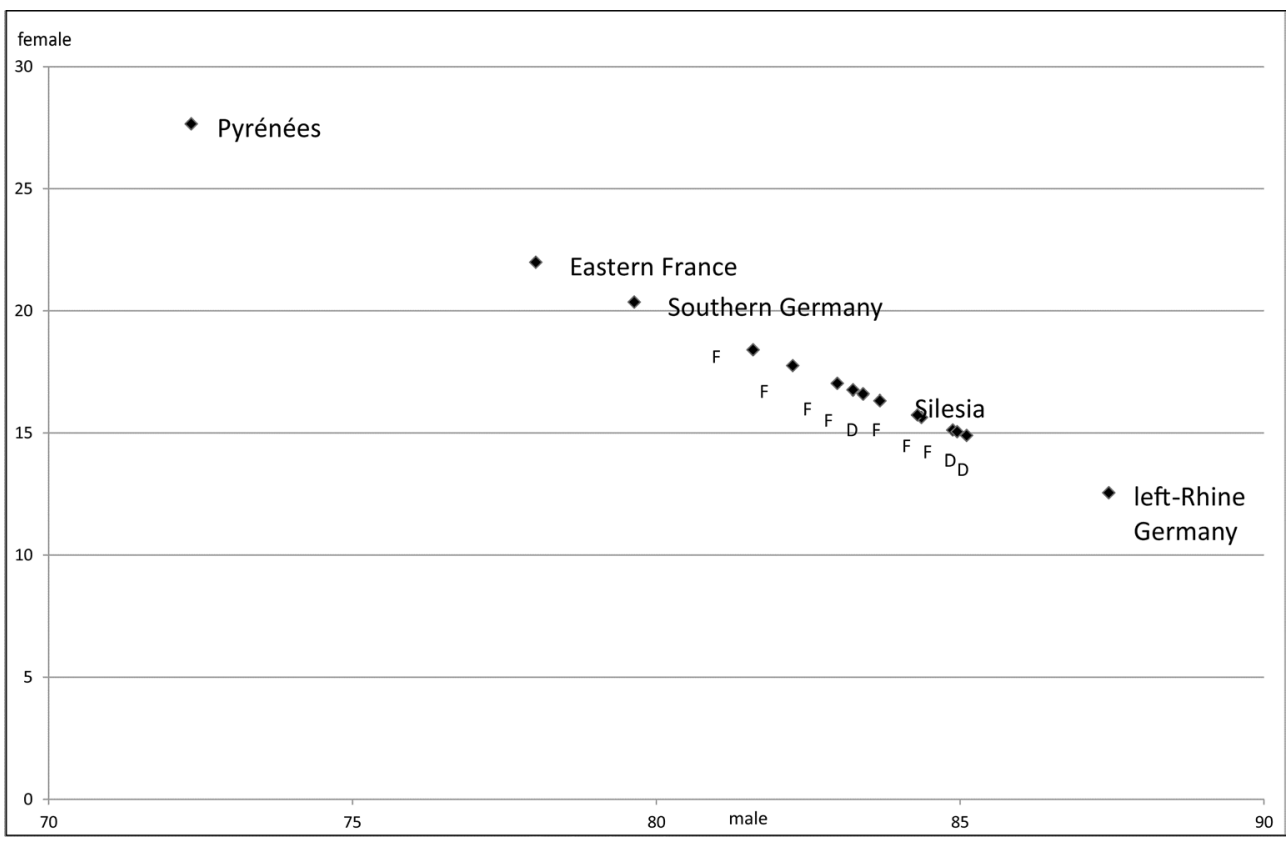

FIG. 3 Percentage of households headed by women,

French and German regions 1846

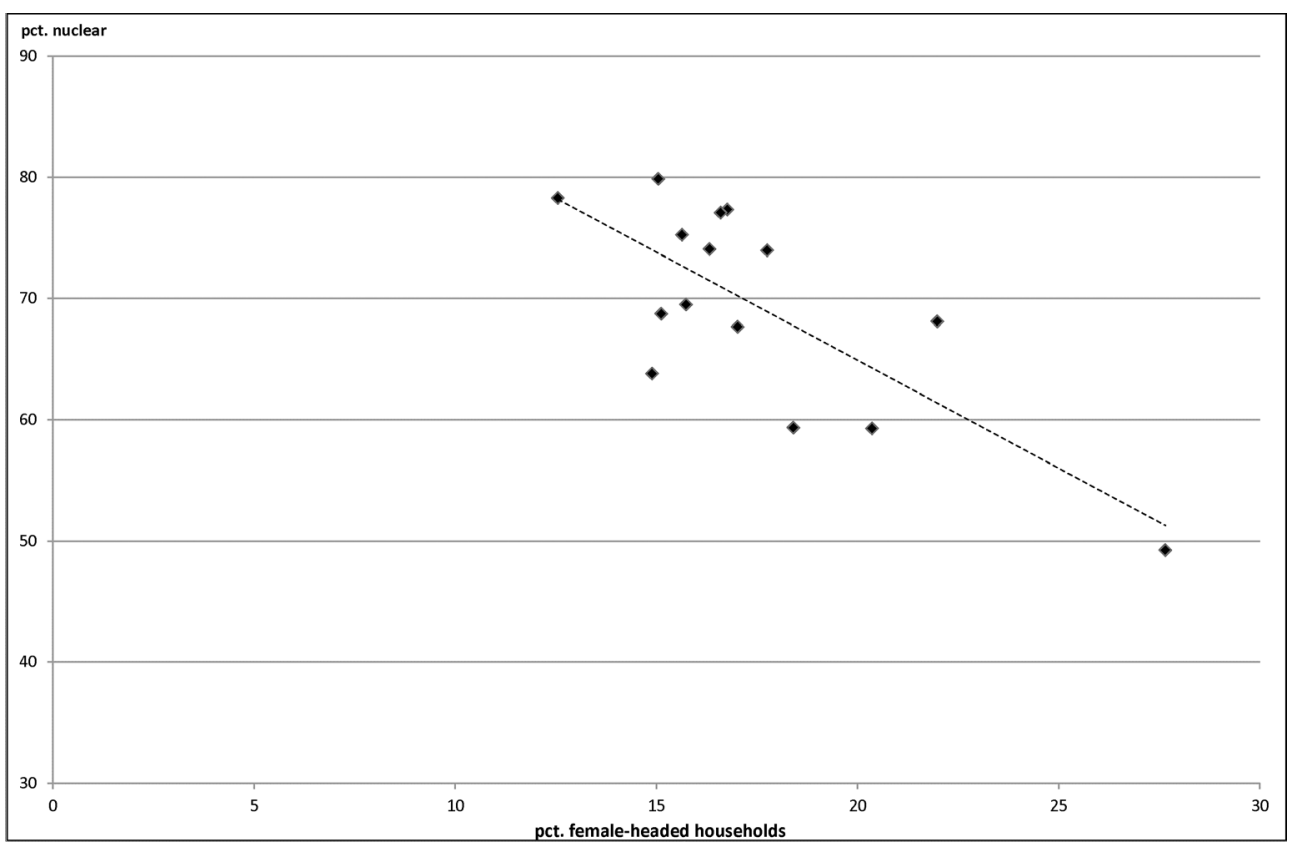

FIG. 4 Correlation between household forms and female headed households 
Monográfico | Women as heads of households in Germany and France: evidence from the 1846 censuses

\begin{tabular}{|l|l|c|c|c|c|c|c|c|c|c|c|}
\hline & & spouse & \multicolumn{3}{|c|}{ widowed } & \multicolumn{3}{|c|}{ unmarried } & \multicolumn{3}{|c|}{ total } \\
\hline & & absent & alone & \& childr. & \& others & alone & \& childr. \& others & \multicolumn{2}{c|}{$\mathrm{n}$} & over all \\
\hline Germany & $\mathrm{n}$ & 22 & 93 & 349 & 38 & 76 & 62 & 20 & 660 & 4308 \\
\hline & pct. & 3.3 & 14.1 & 52.9 & 5.8 & 11.5 & 9.4 & 3.0 & 100 & 15.3 \\
\hline France & $\mathrm{n}$ & 58 & 188 & 284 & 51 & 88 & 40 & 45 & 754 & 4176 \\
\hline & pct. & 7.7 & 24.9 & 37.7 & 6.8 & 11.7 & 5.3 & 6.0 & 100 & 18.1 \\
\hline
\end{tabular}

TABLE 1 . Living conditions of women as household heads

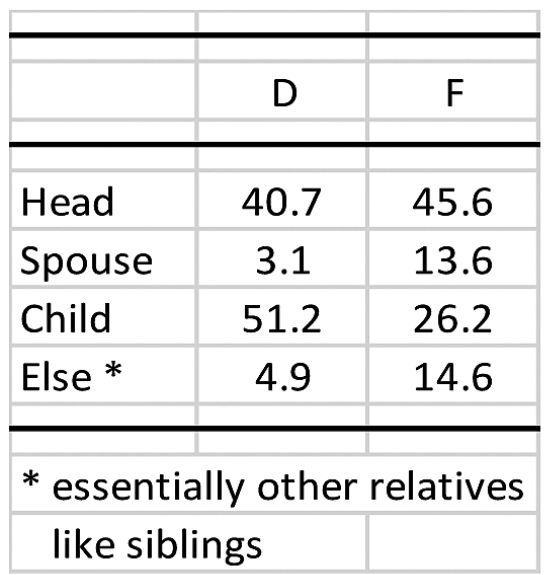

TABLE 2 . Position of mothers of illegitimate children in households 


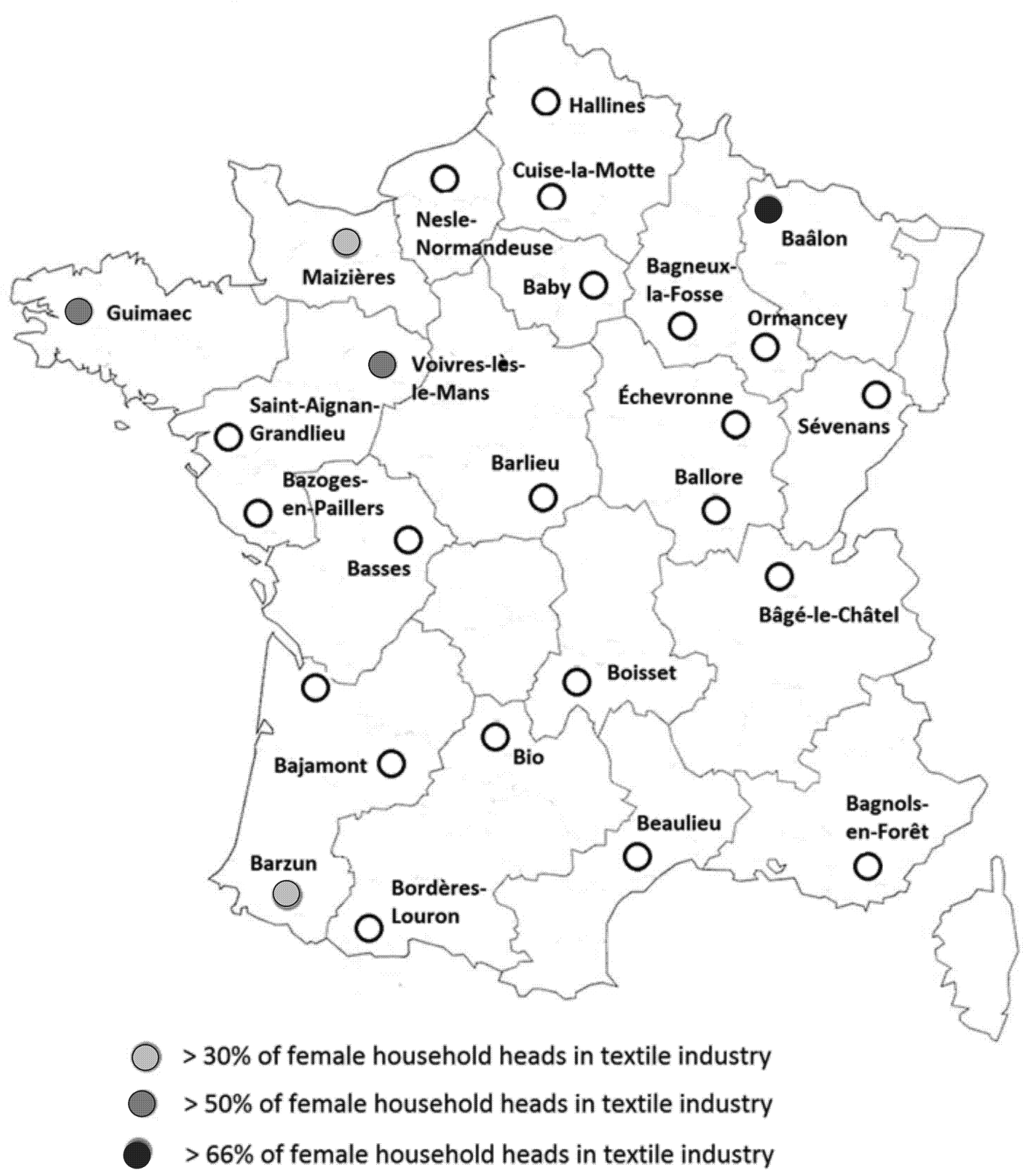

FIG. 5 Female households in the sample of French census lists, 1846 
Monográfico | Women as heads of households in Germany and France: evidence from the 1846 censuses

\begin{tabular}{|l|c|c|c|c|c|c|c|c|}
\hline & \multicolumn{3}{|c|}{ widowed } & \multicolumn{3}{c|}{ unmarried } & sepa- & \\
\hline & alone & \& child & \& others & alone & \& child & \& others & rated & total \\
\hline rural & 2.2 & 8.4 & 0.5 & 1.8 & 1.4 & 0.5 & 0.5 & 15.3 \\
\hline urban & 2.8 & 11.4 & 1.5 & 1.8 & 1.8 & 1.0 & 0.4 & 20.7 \\
\hline rural & 93 & 364 & 23 & 76 & 62 & 20 & 22 & 660 \\
\hline urban & 68 & 277 & 36 & 45 & 45 & 25 & 9 & 505 \\
\hline
\end{tabular}

TABLE 3 Rural and urban female headed households, Germany 1846

\begin{tabular}{|l|r|r|r|r|}
\hline living with: & rural & urban & rural (0/00) & urban (0/00) \\
\hline housemates (families) & 1 & 4 & 0.2 & 1.6 \\
\hline housemates (women) & 4 & 11 & 0.9 & 4.5 \\
\hline employees & 5 & 0 & 1.2 & 0.0 \\
\hline domestic servants & 13 & 15 & 3.0 & 6.2 \\
\hline foster children & 7 & 10 & 1.6 & 4.1 \\
\hline grandchildren & 0 & 5 & 0.0 & 2.1 \\
\hline brothers & 2 & 3 & 0.5 & 1.2 \\
\hline sisters & 6 & 5 & 1.4 & 2.1 \\
\hline other relatives & 3 & 7 & 0.7 & 2.9 \\
\hline others & 1 & 1 & 0.2 & 0.4 \\
\hline
\end{tabular}

TABLE 4 Single women without own children in their household (widows and singlewomen, totals per thousand households) 